\title{
CADERNO
}

\section{PAUL RICEUR}

Phainomenon, n. ${ }^{\circ}$ 15, Lisboa, pp.91-92

DOI: 10.2478/phainomenon-2008-0005

(C) 2008 Henriques. This is an open access article licensed under the Creative Commons AttributionNonCommercial-NoDerivs License (http://creativecommons.org/licenses/by-nc-nd/3.0/). 



\section{INTRODUÇÃO}

Este caderno sobre o pensamento de Paul Ricœur foi concebido em 2005, logo após a morte do filósofo. Vicissitudes várias determinaram que só agora pudesse ter vindo a lume. $\mathrm{O}$ objectivo, contudo, não se alterou com o tempo. Em 2005, como agora, o caderno destina(va)-se a homenagear o filósofo e o cidadão que foi Ricœur, cuja vida e obra estiveram sempre presentes na dinâmica viva do desenrolar cultural e político, para cuja espessura a sua filosofia quis contribuir. E como, na sua época, a polis, como lugar da vida pública/política, já era uma megapolis, uma polis global, a sua filosofia, enquanto pensamento do seu tempo, foi acolhida em todas as latitudes, onde suscitou ressonâncias várias. Desse modo, embora Paul Ricœur nunca tenha sido um filósofo da moda, nem a sua obra tenha tido a recepção compatível com o seu real valor, ela penetrou, contudo, nos diferentes espaços teóricos que estruturam o debate e a reflexão contemporânea, tornando-se uma das referências mais reiteradas desses debates.

O presente caderno quis dar, simultaneamente, a dimensão de compromisso do pensamento ricœuriano e a sua ressonância global, pelo que integra cinco textos que cumprem esses dois objectivos.

O primeiro texto, Le philosophe, l'architecte et la Cité, é de autoria de Jérôme Porée e procura mostrar a capacidade da filosofia de Paul Ricœur não só para ajudar a pensar a Cidade, mas também para ajudar a concebê-la, arquitectonicamente e, assim, permitir a configuração do viver aos diferentes níveis da sua constituição. $\mathrm{O}$ autor quis ainda completar o seu artigo com um texto do próprio Ricœur sobre o tema: trata-se de um discurso proferido na Câmara Municipal de Rennes, cidade onde Ricœur viveu e estudou, e cuja divulgação foi possível por gentileza da Fundação Paul Ricœur.

O segundo texto, Una aproximación a la teoria hermenéutica de la imaginación de Paul Ricaur: de la metáfor al imaginario social, pertence a um autor argentino, Angel Frederico Anaya Leythe, e ocupa-se de uma das incursões importantes da hermenêutica ricœuriana: possibilitar uma compreensão filosófica do fenómeno social.

O terceiro texto, A compreensão na hermenêutica ricœuriana, de João Amaral Ribeiro, é o único texto inserido no caderno que releva da investigação portuguesa sobre o pensamento de Paul Ricœur. Nele o autor dá uma 
visão sistemática da Hermenêutica de Ricœur, do ponto de vista de uma teoria da compreensão.

O quarto texto, Pessoa, Temporalidade e Liberdade, vem do Brasil e é um dos trabalhos que Constança Marcondes César dedicou à hermenêutica francesa, um dos pólos da sua investigação. No presente estudo, a autora mostra a importância da temporalidade para a compreensão do conceito de acção em Ricœur, enquanto cerne das temáticas da pessoa e da liberdade.

O último texto é do próprio Ricœur - numa tradução feita especialmente para este caderno e, igualmente, sob a autorização da Fundação Paul Ricœur. Com o título Os Três Níveis do Juizo Médico, desenvolve uma reflexão acerca da complexidade da actividade médica, relevando de um importante corpo de estudos da filosofia ricœuriana sobre o triângulo Bem, Legalidade e Justiça e de que as obras Le Juste e Le Juste 2 fornecem a configuração essencial. A tradução é precedida de uma introdução, onde se justifica e legitima a escolha do texto, ao mesmo tempo que se faz o seu enquadramento dentro do pensar de Paul Ricœur.

Fernanda Henriques 